\title{
Debt sustainability and the fiscal reaction function: evidence from MIST countries
}

\author{
Lawrence Ogbeifun ${ }^{1 *}$ and Olatunji Shobande ${ }^{2}$
}

\begin{abstract}
The use of public debt is not new in financing developmental objectives. A significant challenge arose when it became obvious that the indebted countries could not fulfill its existing financial obligation to the rest of the world where debt is sourced. For a panel of 4 heterogeneous countries from 1990 to 2017, we study governments' reactions to debt accumulation and the corrective measures taken when its borrowings result in a rise in debt-GDP ratio. The study evidence is based on the fixed effect and the feasible generalized least squares estimators. We find evidence that primary balance improves by about $0.005-0.013$ for every 1 percentage point increase in central government debt after controlling for other relevant factors. The results further suggest that the accrued interest payments on debt reflect the effective debt management policies across the countries, whereas the activities on the current account balance impose a possible threat to the primary balance. The study calls for policies that increase fiscal bases through the reduction in fiscal expenditure and the reinforcement of tax base revenue across the MIST countries.
\end{abstract}

\section{Introduction}

Investment opportunities in Mexico, Indonesia, South Korea, and Turkey (henceforth MIST countries) in the last decade have become more attractive based on expectations for high growth due to their favorable demographics and fast-paced economies. However, there are many concerns that excessive practice of fiscal deficit or heavy reliance on debt may have adverse effects on the economic progress in many ways $[19,41,42]$. One primary concern for debt sustainability in MIST countries is the growth in a debt burden that is likely to result in a disparity between interest and exchange rate with a negative attendant to expected inflation which might result in a liquidity trap and economic hardship. The second concern is the possibility that MIST countries might be exposed to exogenous shock due to high private indebtedness which has weighed on its economic outlook in recent times. Hence, in this study, it becomes important to analyze debt sustainability among MIST countries

\footnotetext{
*Correspondence: logbeifu@go.olemiss.edu

1 Department of Economics, University of Mississippi, Oxford, MS 38677, USA

Full list of author information is available at the end of the article
}

because proper debt management is a critical ingredient for a stable economy.

Debt sustainability is widely acknowledged as the ability of a country to meet its financial obligation without being subject to the external rescue [36]. IMF [27] describes debt sustainability as the need to satisfy solvency condition without subject to correction or additional cost of financing. To further highlight the importance of debt sustainability, some studies claimed that such solvency condition must ensure that public debt plus the discount value of entirely government spending does not exceed the present value of generated revenues of non-interest spending $[14,32]$.

Public debt is an important instrument used by sovereign governments to manage their fiscal imbalance that arises out of mismatches between revenue generation and expenditure needs [29]. Due to the large fiscal imbalance faced by most countries, the government resorts to an external source of revenue in the form of borrowing to augment its internal revenue. While this practice in itself is not bad, an excess accumulation of debt creates serious fiscal problem for both current and future generations if not properly managed $[4,18]$. This is because mismanagement of external borrowing has little or no significant 
impact on the gross domestic product (GDP) thereby increasing the debt-to-GDP ratio and draining out government revenue via debt servicing and interest payment. On the other hand, when debt is properly managed for the purpose to which it was borrowed, it boosts the GDP and reduces the debt-to-GDP ratio.

The obvious question is whether the current macroeconomic policies in MIST countries can avert financial crises which question the essence of revisiting its level of public debt accumulation. This further questions the importance of macroeconomic policy and the effectiveness of debt management in reducing fluctuation that is expected should in case the financial obligation cannot be met $[33,50]$. In addition, the present inconsistency observed in the external asset and liability of the MIST countries shows the possibility that setbacks in growth are expected. Thus, earlier signals to prevent the occurrence call for the need to address the MIST debt sustainability problem. Some studies have claimed that poor supervision of the financial institution coupled with lack of fiscal discipline is a new channel through which public debt can become a dilemma, especially when the gap between the rich and the poor becomes obvious [20, $25,45]$. It became more serious when the people cannot guarantee the safety of funds, due to expected financial crises.

Many theoretical papers have claimed that debt sustainability is not only explained by the threshold in the level of debt-to-GDP ratio, but the ability of a country to fulfill is debt obligation [28, 37]. The group of theoretical papers claims would argue that grave concern is more when the foreign currency is preferred to a domestic currency which often leads to financial crises. Besides, the vast majority of studies have suggested that the source of government financing does not matter, but the spending structure should be significant attention $[4,18]$, but this study undermines the possibility that unsustainable of debt can have a varied consequence on investment, consumption, and output level. Thus, it would appear this suggestion took for granted the option that public debt can have a different effect on the economy both internally and externally.

In the earlier empirical literature, studies by Hamilton and Flavin [24], Wilcox [48], Trehan and Walsh [44], and Bohn [11] examine fiscal debt sustainability through the use of nonstationary time series analysis. Hamilton and Flavin [24] focus on the stochastic properties of the deficit inclusive-of-interest payments and found that fiscal policy is sustainable. In contrast with their result, Wilcox 48 by allowing for stochastic real interest rates found that the US fiscal policy has not been sustainable in the scope of its study. Trehan and Walsh [44] show that in studying government expenditure and financing decisions, intertemporal budget balance can be imposed easily by estimating a vector error correction model that includes the inclusive-of-interest deficit as the error correction term. Bohn [11] showed that sustainability is compatible with any order of integration of the variables involved.

Bohn $[9,10]$ proposed a different test on sustainability. It states that public debt policy is sustainable if the primary surplus-GDP ratio is a positive function of the debt-GDP ratio. The plausible economic intuition is that if government run into debt, they have to take corrective actions on the future by increasing the primary surplus in order for public debt to be sustainable [6]. Specifically, Bohn [10] has suggested that the deciding fiscal policy soundness should not be restricted to the evaluation of stationarity of the debt-to-GDP ratio and provides a new sustainability test that does not require interest rate assumptions. More recently, Fournier and Fall [21] and Ghosh et al. [22, 23] have used fiscal reaction functions for the estimation of public debt sustainability thresholds and public debt limits aimed at providing possible measures of fiscal space. Also, Checherita-Westphal and Ždárek [16]) propose to use fiscal reaction functions to derive primary balance benchmarks used to identify fiscal fatigue risks. Their result shows that after controlling for relevant factors, primary balance improves in the euro area by about $0.03-0.05$ for every 1 percentage point increase in the debt-to-GDP ratio.

Earlier evidence failed to account for the possibility of the role of current account management and business cycles play in public debt sustainability. ${ }^{1}$ The few consensuses rely deeply on the disparities in debt-to-GDP ratio and solvency transmission mechanism [39]. In this paper, we study governments' reactions to the accumulation of debt, taking into account the crucial role of the current account balances. Also, we look at whether the government takes corrective measures when the debt-GDP ratio starts rising or just let the debt grow, knowing fully well of its consequences for public debt (non)sustainability. With this purpose, for a panel of four countries from 1990 to 2017, we investigate the existence of a systematic relationship between debt and primary balance series. We claimed that the ability of these countries to meet their financial obligations is not the only contributory factor to their economic misfortune. We argue that MIST countries share similar consequences of focusing on inflation targeting which does not reassure stability nor help reduce their debt vulnerability. We further claim that excessive debt accumulation in MIST countries is the

\footnotetext{
${ }^{1}$ See Tanner and Samake [43], Islam and Biswas [26], Makin [35], Ahmed [2], Mahmood and Rauf [34], Kaur et al. [31], Agnello and Sousa [1], and Renjith and Shanmugam [40].
} 
consequence of credit rationing which are erosion from the capital market and spillover from external shock.

\section{Methods \\ Model and data}

To set up the framework for this study, we begin by stating the budget equation which shows the relation between public debt, $D_{t}$, and primary balance, $S_{t}$ : $D_{t+1}=\left(D_{t}-S_{t}\right)\left(1+R_{t+1}\right)$, where $R_{t}$ is the nominal interest rate and $1+R_{t+1}$ is the gross interest factor. Considering a growing economy with growing government expenditure and growing tax base, the evolution of the budget equation in terms of debt-to-GDP ratio is

$$
\frac{D_{t+1}}{Y_{t+1}}=\left[\frac{D_{t}}{Y_{t}}-\frac{S_{t}}{Y_{t}}\right] \frac{Y_{t}}{Y_{t+1}}\left(1+R_{t+1}\right)
$$

which can be simplified as

$$
d_{t+1}=\left[d_{t}-s_{t}\right] x_{t+1}
$$

where $Y_{t}$ is the actual GDP, $d_{t}=\frac{D_{t}}{Y_{t}}$ is the ratio of general government debt to GDP, $s_{t}=\frac{S_{t}}{Y_{t}}$ denote primary balance to GDP ratio, and $\left(1+R_{t+1}\right) \approx 1+r_{t+1}-y_{t+1}$ denotes the ratio of gross return on government debt to the gross growth rate of GDP. The variables $y_{t+1}$ and $r_{t+1}$ denote the real growth rate and the real interest rate, respectively.

To complement the theoretical approach of Blanchard et al. [8] and other more complex sustainability frameworks, Bohn [10] provided a new test of sustainable fiscal policy by relating the primary balance to the level of debt, with or without conditioning on further controls. This is written as:

$$
p b_{t}=\alpha_{t}+\left[\theta * d_{t}\right]+\xi_{t}
$$

where $p b_{t}$ is the primary balance as a percentage of GDP, $d_{t}$ is the government debt-to-GDP ratio, $\theta$ measures the responsiveness of the primary balance to the debt ratio, and $\xi_{t}$ contains other determinants of primary balance and the error term.

For an economy to satisfy its intertemporal budget constraint and the so-called no-Ponzi condition, the coefficient $\theta>0$ is sufficient provided the present value of GDP is finite and $\xi_{t}<\infty$ as a fraction of GDP as well. ${ }^{2}$ However, other studies ${ }^{3}$ have shown that a positive coefficient $\theta$ cannot be viewed as a sufficient condition to achieve fiscal sustainability, especially if there is a limit for positive values of primary balance, for instance, at a very high debt level, or if the reaction of financial market is

\footnotetext{
${ }^{2}$ See Bohn [12].

${ }^{3}$ See Daniel and Shiamptanis [17] and Ghosh et al. [22, 23].
}

accounted for. In such situations, the Bohn's condition is a "weak sustainability condition."

The empirical model for this study is an extension of the relationship given in Eq. (3):

$$
\begin{aligned}
p b_{i, t}= & \alpha+\delta * p b_{i, t-1}+\left[\theta * d_{i, t-1}\right] \\
& +\left[\beta * X_{i, t}\right]+\gamma_{i}+\lambda_{t}+\in_{i, t} .
\end{aligned}
$$

where $p b_{i, t}$ is the primary balance as a share of GDP and $p b_{i, t-1}$ is its one year lagged value which determines the interest payment in the current period, $d_{i, t-1}$ is the 1 year lagged debt-to-GDP ratio, $X_{i, t}$ is a vector of macro(economic) and political determinants of the primary balance, $\gamma_{i}$ are country fixed effect included to capture all other time-invariant country-specific factors that are not explicitly controlled for and $\lambda_{t}$ are time dummies; the error term, $\in_{i, t}$, captures measurement errors and random shocks.

In the fiscal reaction function (FRF) literature, two main policy variables - the cyclically adjusted primary balance $(\mathrm{CAPB})$ or the primary balance $(\mathrm{PB})$ - have been used as a dependent variable. ${ }^{5}$ Following most studies, we prefer to use $\mathrm{PB}$ as the dependent variable since it is the "observable" fiscal policy that is less prone to ex-post revisions (due to output gap and elasticity's' uncertainty). ${ }^{6}$

In choosing determinants of the fiscal position, we follow the work of Baig and Abiad [5]. In their study, these determinants are divided into three main groups: (1) optimizing agent, (2) political economy consideration, and (3) institutional factors that shape the policy environment and the use of fiscal measures. The "Base" FRF model includes the lagged of debt-to-GDP ratio-that is central government debt (CGD) - and 1 year lagged of primary balance as the independent variable, and as for the determinants of primary balance, we use interest payment on the public debt (INTP), current account balance $(\mathrm{CAB})$, business cycle variable (YVAR), and Election year dummy (EY). ${ }^{7}$ The main data source for our analysis is the World Development Indicators (WDI, [49]) and the International Monetary Fund (IMF).

\footnotetext{
${ }^{4}$ Ghosh et al. [22, 23].

5 As defined by the Organization of Economic Co-operation and Development (OECD), primary balance is overall balance excluding net interest payment (interest expenditure minus interest revenue), while cyclically adjusted primary balance is the difference between the cyclical component of the overall fiscal balance-computed as the difference between cyclical revenues and cyclical expenditures - and the automatic stabilizers, excluding net interest payment.

6 See Checherita-Westphal and Ždárek [16].

7 Current account balance (CAB) to control for cross-country spillovers and the hypothesis of twin deficits, and Election year dummy (EY) account for political risk variable. YVAR is obtained by applying the HP Filter twice on GDP series (see [3].
} 
Table 1 Summary statistics of the variables considered in model. Source: Authors' computation (2020)

\begin{tabular}{lrr}
\hline Variables & Mean & \multicolumn{1}{c}{ SD } \\
\hline PB & 1.448 & 1.727 \\
CGD & 31.694 & 14.503 \\
INTP & 3.731 & 4.470 \\
CAB & -4.156 & 27.822 \\
YVAR & -0.003 & 0.124 \\
\hline
\end{tabular}

\section{Empirical methodology}

The study applies Pesaran [38] unit root test to ascertain the order of integration of the variables in the model since it tolerates cross-sectional dependence. To provide evidence in favor of the cointegration hypothesis, we apply the Pedroni residual-based cointegration test and the Westerlund [46] tests on cointegration. Finally, the model is estimated using the fixed effect (FE) estimator allowing for the presence of potentially endogenous variables. Being aware of criticisms of its use, we argue that our panel is medium to large in the time dimension compared to the cross-sectional dimension and the potential bias should be limited-the "rule of thumb" based on Bond [13] states that for cases when $T$ is larger than 20, the potential bias of the FE estimator should be negligible. ${ }^{8}$ We use the feasible GLS (FGLS) to correct for any possible heteroscedasticity and cross-sectional dependence problem.

\section{Empirical results}

\section{Descriptive statistics}

Table 1 reports the summary statistics to the variables relevant for the analysis presented here. The average value and related deviation of the primary balance $(\mathrm{PB})$ stood at 1.45 (1.73), while for the central government debt (CGD) 31.69 (14.50), interest payment (INTP) 3.73 (4.47), current account balance $(\mathrm{CAB})-4.16$ (27.82), and the business cycle variable (YVAR) $-0.003(0.124)$.

\section{Correlation analysis}

The correlation results presented in Table 2 show that multicollinearity is not a problem in this study. This is because all the regressors are not strongly correlated. The central government debt, interest payment, and current account balance are positively correlated with primary balance at $18.7 \%, 27.7 \%$, and about $0.9 \%$, respectively, while the business cycle variable has a negative

\footnotetext{
${ }^{8}$ It has been shown that GMM estimators would not alleviate the problem. See Judson and Owen [30] and Celasun and Kang [15].
}

Table 2 Correlation of variables. Source: Authors' computation (2020)

\begin{tabular}{lrrrrr}
\hline & \multicolumn{1}{l}{ PB } & \multicolumn{1}{l}{ CGD } & INTP & CAB & YVAR \\
\hline PB & 1.0000 & & & & \\
CGD & 0.1879 & 1.0000 & & & \\
INTP & 0.2770 & 0.4273 & 1.0000 & & \\
CAB & 0.0089 & 0.1100 & -0.1396 & 1.0000 & \\
YVAR & -0.0353 & -0.3816 & -0.1808 & -0.2008 & 1.0000 \\
\hline
\end{tabular}

Table 3 CD test results. Source: Authors' computation (2020)

\begin{tabular}{lcl}
\hline Tests & Statistic & Probability \\
\hline Null hypothesis: there is no CD among selected countries & \\
Frees test & $0.8760^{* * *}$ & \\
Frees' Q distribution & 0.0924 & $10 \%$ \\
& 0.1204 & $5 \%$ \\
& 0.1726 & $1 \%$ \\
Pesaran CD test & $5.462^{* * *}$ & 0.0000 \\
Friedman test & $64.818^{* * *}$ & 0.0000 \\
Breusch-Pagan LM & $38.194^{* * *}$ & 0.0000 \\
\hline
\end{tabular}

***1\% significance level

correlation with primary balance at $3.5 \%$. Going by this result, we proceed with the other estimations.

\section{Cross-sectional dependence $(C D)$ test}

The cross-sectional dependence (CD) tests displayed in Table 3 indicates a strong $C D$ among the countries. The Frees test, Pesaran CD test, Friedman test, and BreuschPagan LM test are all significant at a $1 \%$ significance level. Hence, we reject the null hypothesis of no cross-sectional dependence and confirm that there is strong dependence among the 4 countries selected. The economic implication is that government debt policies adopted by any of the MIST countries have transboundary impacts on the other countries.

\section{Panel unit root test and cointegration test}

With the presence of $\mathrm{CD}$, the first generation panel unit root becomes inadequate; hence, we use the second generation panel unit root test of Pesaran [38] in Table 4. The results show that $\mathrm{PB}, \mathrm{CGD}$, and YVAR are $I(1)$ stationary at the $1 \%$ significance level after first difference, whereas INTP and CAB are $I(0)$ stationary at a $1 \%$ significance level. The values of the statistics in Table 5 suggest that we can reject the null hypothesis of no cointegration at the $5 \%$ level for both tests. 
Table 4 Pesaran [38] panel unit root test Source: Authors' computation (2020)

\begin{tabular}{|c|c|c|c|c|c|}
\hline Variables & CIPS stat. level & $P$ value & CIPS stat. first diff & $P$ value & $\begin{array}{l}\text { Order } \\
\text { of integration }\end{array}$ \\
\hline PB & -1.615 & 0.053 & -5.314 & $0.000^{* * *}$ & $/(1)$ \\
\hline CGD & 0.214 & 0.585 & -4.143 & $0.000^{* * *}$ & $/(1)$ \\
\hline INTP & -3.336 & $0.000^{* * *}$ & - & - & $I(0)$ \\
\hline YVAR & 1.115 & 0.868 & -4.111 & $0.000^{* * *}$ & $/(1)$ \\
\hline$C A B$ & -4.290 & $0.000^{* * *}$ & - & - & $I(0)$ \\
\hline
\end{tabular}

***1\% significance level

Table 5 Panel cointegration test. Source: Authors' computation (2020)

\begin{tabular}{lll}
\hline & Pedroni test & Westerlund test \\
\hline Modified PP statistic & $1.7236^{* *}$ & \\
& $(0.0424)$ & \\
PP statistic & 1.8787 & \\
& $(0.4475)$ & \\
ADF statistic & 0.9548 & \\
& $(0.1698)$ & $2.1416^{* *}$ \\
Variance ratio & & $(0.0161)$ \\
\hline
\end{tabular}

**5\% significance level

\section{Baseline estimate and extended models}

The results from the fixed effect (FE) regression are reported in Table 6 . The choice of the fixed effect model over the random effect model is justified by the Hausman test results. The Base model in column [1] is estimated without a time fixed effect. The estimated FRF coefficient of interest-the response to government debt (CGD) - is positive and statistically significant and amount to 0.019 . The explanatory power as measured by the goodness of fit statistics is 0.525 . In column [2], including the time fixed effect in the Base model improves the explanatory power. The FRF coefficient is slightly lower and remains statistically significant.

Table 6 Basic model and extended specifications, fixed effect. Source: Authors' computation (2020)

\begin{tabular}{|c|c|c|c|c|c|c|c|c|}
\hline & 1 & 2 & 3 & 4 & 5 & 6 & 7 & 8 \\
\hline \multicolumn{9}{|c|}{ Dependent variables: primary balance (PB) } \\
\hline Lagged PB & $\begin{array}{l}0.683^{* * *} \\
(0.069)\end{array}$ & $\begin{array}{l}0.575^{* * *} \\
(0.098)\end{array}$ & $\begin{array}{l}0.668^{* * *} \\
(0.069)\end{array}$ & $\begin{array}{l}0.677^{* * *} \\
(0.069)\end{array}$ & $\begin{array}{l}0.683^{* * *} \\
(0.070)\end{array}$ & $\begin{array}{l}0.683^{* * *} \\
(0.069)\end{array}$ & $\begin{array}{l}0.654^{* * *} \\
(0.070)\end{array}$ & $\begin{array}{l}0.596^{* * *} \\
(0.099)\end{array}$ \\
\hline Lagged CGD & $\begin{array}{l}0.019^{* *} \\
(0.009)\end{array}$ & $\begin{array}{l}0.012^{* *} \\
(0.002)\end{array}$ & $\begin{array}{l}0.015^{* *} \\
(0.002)\end{array}$ & $\begin{array}{l}0.023^{* *} \\
(0.009)\end{array}$ & $\begin{array}{l}0.019 * * \\
(0.009)\end{array}$ & $\begin{array}{l}0.020^{* *} \\
(0.009)\end{array}$ & $\begin{array}{l}0.020^{* *} \\
(0.009)\end{array}$ & $\begin{array}{l}0.013^{* *} \\
(0.004)\end{array}$ \\
\hline INTP & & & $\begin{array}{l}0.061^{*} \\
(0.033)\end{array}$ & & & & $\begin{array}{l}0.075^{* *} \\
(0.035)\end{array}$ & $\begin{array}{l}0.026^{* *} \\
(0.005)\end{array}$ \\
\hline$C A B$ & & & & $\begin{array}{l}-0.006 \\
(0.005)\end{array}$ & & & $\begin{array}{l}-0.009 \\
(0.006)\end{array}$ & $\begin{array}{l}-0.003 \\
(0.038)\end{array}$ \\
\hline YVAR & & & & & $\begin{array}{l}0.038 \\
(0.928)\end{array}$ & & $\begin{array}{l}0.060 \\
(0.954)\end{array}$ & $\begin{array}{l}0.815 \\
(0.901)\end{array}$ \\
\hline EY & & & & & & $\begin{array}{l}0.165^{* * *} \\
(0.019)\end{array}$ & $\begin{array}{l}0.150^{* * *} \\
(0.021)\end{array}$ & $\begin{array}{l}0.368^{* * *} \\
(0.091)\end{array}$ \\
\hline Constant & $\begin{array}{l}-0.237 \\
(0.309)\end{array}$ & $\begin{array}{l}0.271 \\
(0.573)\end{array}$ & $\begin{array}{l}-0.310 \\
(0.308)\end{array}$ & $\begin{array}{l}-0.365 \\
(0.333)\end{array}$ & $\begin{array}{l}-0.240 \\
(0.317)\end{array}$ & $\begin{array}{l}-0.275 \\
(0.317)\end{array}$ & $\begin{array}{l}-0.560 \\
(0.346)\end{array}$ & $\begin{array}{l}0.149 \\
(0.346)\end{array}$ \\
\hline$R^{2}$ & 0.525 & 0.748 & 0.540 & 0.530 & 0.530 & 0.526 & 0.552 & 0.757 \\
\hline No. of observation & 108 & 108 & 108 & 108 & 108 & 108 & 108 & 108 \\
\hline Country FE & Yes & Yes & Yes & Yes & Yes & Yes & Yes & Yes \\
\hline Time FE & No & Yes & No & Yes & No & No & No & Yes \\
\hline Hausman & {$[0.004]$} & {$[0.017]$} & {$[0.043]$} & {$[0.012]$} & {$[0.049]$} & {$[0.041]$} & {$[0.033]$} & {$[0.037]$} \\
\hline \multicolumn{9}{|l|}{ Diagnostic test } \\
\hline B-P LM & {$[0.049]$} & {$[0.049]$} & {$[0.117]$} & {$[0.072]$} & {$[0.050]$} & [0.039] & [0.239] & [0.289] \\
\hline CD test & {$[0.001]$} & {$[0.001]$} & {$[0.002]$} & {$[0.001]$} & {$[0.001]$} & {$[0.000]$} & [0.004] & {$[0.002]$} \\
\hline M-Wald test & {$[0.000]$} & {$[0.000]$} & {$[0.000]$} & {$[0.000]$} & {$[0.000]$} & {$[0.000]$} & {$[0.000]$} & {$[0.000]$} \\
\hline
\end{tabular}

italic values denote main variable of interest 
Table 7 Basic model and extended specifications, feasible GLS Source: Authors' computation (2020)

\begin{tabular}{|c|c|c|c|c|c|c|c|c|}
\hline & 1 & 2 & 3 & 4 & 5 & 6 & 7 & 8 \\
\hline \multicolumn{9}{|c|}{ Dependent variables: primary balance (PB) } \\
\hline Lagged PB & $\begin{array}{l}0.729^{* * *} \\
(0.064)\end{array}$ & $\begin{array}{l}0.659^{* * *} \\
(0.076)\end{array}$ & $\begin{array}{l}0.714^{* * *} \\
(0.065)\end{array}$ & $\begin{array}{l}0.730 * * * \\
(0.064)\end{array}$ & $\begin{array}{l}0.731^{* * *} \\
(0.064)\end{array}$ & $\begin{array}{l}0.726^{* * *} \\
(0.065)\end{array}$ & $\begin{array}{l}0.712^{* * *} \\
(0.065)\end{array}$ & $\begin{array}{l}0.650^{* * *} \\
(0.076)\end{array}$ \\
\hline Lagged CGD & $\begin{array}{l}0.013^{* *} \\
(0.007)\end{array}$ & $\begin{array}{l}0.005^{* *} \\
(0.001)\end{array}$ & $\begin{array}{l}0.010^{* *} \\
(0.002)\end{array}$ & $\begin{array}{l}0.013^{*} \\
(0.006)\end{array}$ & $\begin{array}{l}0.012^{*} \\
(0.007)\end{array}$ & $\begin{array}{l}0.013^{*} \\
(0.007)\end{array}$ & $\begin{array}{l}0.009^{* *} \\
(0.001)\end{array}$ & $\begin{array}{l}0.005^{*} \\
(0.001)\end{array}$ \\
\hline INTP & & & $\begin{array}{l}0.038^{* *} \\
(0.013)\end{array}$ & & & & $\begin{array}{l}0.041^{* *} \\
(0.015)\end{array}$ & $\begin{array}{l}0.022^{* *} \\
(0.003)\end{array}$ \\
\hline$C A B$ & & & & $\begin{array}{l}-0.001 \\
(0.004)\end{array}$ & & & $\begin{array}{l}-0.001 \\
(0.004)\end{array}$ & $\begin{array}{l}-0.002 \\
(0.003)\end{array}$ \\
\hline YVAR & & & & & $\begin{array}{l}0.176 \\
(0.795)\end{array}$ & & $\begin{array}{l}0.006 \\
(0.812)\end{array}$ & $\begin{array}{l}0.818 \\
(0.820)\end{array}$ \\
\hline EY & & & & & & $\begin{array}{l}0.126^{* * *} \\
(0.005)\end{array}$ & $\begin{array}{l}0.147^{* * *} \\
(0.059)\end{array}$ & $\begin{array}{l}0.471^{* * *} \\
(0.232)\end{array}$ \\
\hline Constant & $\begin{array}{l}-0.106 \\
(0.239)\end{array}$ & $\begin{array}{l}0.326 \\
(0.449)\end{array}$ & $\begin{array}{l}-0.114 \\
(0.237)\end{array}$ & $\begin{array}{l}-0.107 \\
(0.240)\end{array}$ & $\begin{array}{l}-0.099 \\
(0.243)\end{array}$ & $\begin{array}{l}-0.128 \\
(0.247)\end{array}$ & $\begin{array}{l}-0.138 \\
(0.247)\end{array}$ & $\begin{array}{l}0.183 \\
(0.346)\end{array}$ \\
\hline No. of observation & 108 & 108 & 108 & 108 & 108 & 108 & 108 & 108 \\
\hline Country FE & Yes & Yes & Yes & Yes & Yes & Yes & Yes & Yes \\
\hline Time FE & No & Yes & No & Yes & No & No & No & Yes \\
\hline \multicolumn{9}{|l|}{ Diagnostic test } \\
\hline M-Wald test & {$[0.064]$} & {$[0.159]$} & {$[0.110]$} & {$[0.650]$} & {$[0.522]$} & {$[0.116]$} & {$[0.220]$} & {$[0.882]$} \\
\hline
\end{tabular}

italic values denote main variable of interest

***, ${ }^{* *},{ }_{1} 1 \%, 5 \%$ and $10 \%$ significance level; []$=p$ value

Following a stepwise approach, we add other variables to the Base model in columns [3]-[4] and noticed a slight improvement in the explanatory power. The FRF coefficients range between 0.015 and 0.023 and remain highly significant. The coefficients of interest payment (INTP) and election year (EY) are both positive and statistically significant, whereas the coefficient of the current account balance $(C A B)$ is negative and not statistically significant. Similarly, the coefficient of the business cycle variablewhich captures the output gap-is generally positive and insignificant. This result is similar to other recent studies, such as Berti et al. [7] and Checherita-Westphal and Ždárek [16]. Columns [7] and [8] show results for models with all the variables, with and without time fixed effect. The FRF coefficient and the explanatory power only improve by a small margin.

The diagnostic test suggests the problem of crosssectional dependence and heteroscedasticity. To correct these problems, Wiggins and Poi [47] suggest the feasible GLS (FGLS). Table 6 shows the results from the FGLS estimates. Across all columns, the FRF coefficients are slightly lower than the counterpart in Table 7; however, they remain positive and statistically significant, which implies that an increase in the central government debt will bring about an increase in primary balance. The economic intuition is that in the long run, the government fiscal policy is sustainable in the MIST countries. This result is a strong signal for investors and borrowers about the economic performance in the MIST countries, which further smoothens the economic confidence among various players in the economic space. We find strong evidence for interest payment (INTP) which highlights the debt management strategy implemented across the MIST countries and suggest a sign of relief for the current and future generations from unnecessary tax burden from the government. While the business cycle variable (YVAR) has a positive impact on the primary balance, the current account balance $(\mathrm{CAB})$ has a negative impact on primary balance although both variables are found not to be significant. This is not surprising as the data show that in most part of the period covered by this study, the current account balance is usually deficit for most of the MIST countries. This reduces the revenue side of the primary balance account, and with the expenditure side on the rise, the net primary balance is expected to fall-ceteris paribus.

"Appendix" includes a robustness check (in Table 8) with respect to the choice of the dependent variablecyclically adjusted primary balance (CABP) instead of primary balance $(\mathrm{PB})$. The results are quite similar to those using $\mathrm{PB}$, but the coefficients of the government debt, which range from 0.001 to 0.008 , are lower compared to those in Table 7. This further justifies our choice for the primary balance, as the FRF coefficients from the cyclically adjusted primary balance might signal weak sustainability. 


\section{Conclusion}

In this article, we examined the relationship between public debt and primary balance in MIST countries. Using a panel dataset from 1990 through 2017, we explore if the fiscal policy follows a sustainable path. Having controlled for the problem of cross-sectional dependence and heteroscedasticity, we found evidence that fiscal policy is sustainable. The primary balance improves by about $0.005-0.013$ for every 1 percentage point increase in central government debt. As regards other determinants, the interest payment result is a huge relief for taxpayers as it reassures them that the governments are on the right path in its debt management practices. The political factor variable-election year-has a strong impact on the primary balance. A possible interpretation is that projects embarked on and the policies announced by the political candidates are mostly followed up, as the data reflect significant increases in the primary balances after election year across the countries.

In conclusion, a possible suggestion to ensure the MIST countries continue to enjoy sustainable fiscal policy in the future is to increase their fiscal bases through the reduction in fiscal expenditures and the reinforcement of tax revenue bases which will help correct for the recurrent deficit in the current account balance and create a favorable debt-GDP ratio.
Abbreviations

MIST: Mexico, Indonesia, South Korea, and Turkey; CGD: central government debt to GDP; INTP: interest payment on public debt; CAB: current account balance; YVAR: business cycle variable; CAPB: cyclically adjusted primary balance; FRF: fiscal reaction function; EY: election year; PB: primary balance; FE: fixed effect; FGLS: feasible generalized least squares.

\section{Acknowledgements}

Not applicable.

\section{Authors' contributions}

O.S. drafted the introduction and theoretical model used for the study. L.O. collected and analyzed the secondary, discussed the result and conclude the study. All authors have read and approved the manuscript.

\section{Funding}

No funding was obtained for this study.

\section{Availability of data and materials}

Datasets used and/or analyzed during the current study are available from the corresponding author on reasonable request.

\section{Competing interest}

The authors declare that they have no competing interests.

\section{Author details}

${ }^{1}$ Department of Economics, University of Mississippi, Oxford, MS 38677, USA ${ }^{2}$ Business School, University of Aberdeen, Block C, Edward Wright Annexes, Aberdeen AB 243 RX, UK.

\section{Appendix: Robustness check}

See Table 8.

Table 8 Basic model and extended specifications with CAPB, feasible GLS. Source: Authors' computation (2020)

\begin{tabular}{|c|c|c|c|c|c|c|c|c|}
\hline & 1 & 2 & 3 & 4 & 5 & 6 & 7 & 8 \\
\hline \multicolumn{9}{|c|}{ Dependent variables: primary balance (CAPB) } \\
\hline Lagged CAPB & $\begin{array}{l}0.811^{* * *} \\
(0.056)\end{array}$ & $\begin{array}{l}0.777^{* * *} \\
(0.071)\end{array}$ & $\begin{array}{l}0.795^{* * *} \\
(0.065)\end{array}$ & $\begin{array}{l}0.795^{* * *} \\
(0.056)\end{array}$ & $\begin{array}{l}0.816^{* * *} \\
(0.056)\end{array}$ & $\begin{array}{l}0.811^{* * *} \\
(0.056)\end{array}$ & $\begin{array}{l}0.779 * * * \\
(0.056)\end{array}$ & $\begin{array}{l}0.734^{* * *} \\
(0.071)\end{array}$ \\
\hline Lagged CGD & $\begin{array}{l}0.008^{* *} \\
(0.005)\end{array}$ & $\begin{array}{l}0.001 \\
(0.005)\end{array}$ & $\begin{array}{l}0.006^{* *} \\
(0.001)\end{array}$ & $\begin{array}{l}0.007^{*} \\
(0.001)\end{array}$ & $\begin{array}{l}0.007^{* *} \\
(0.000)\end{array}$ & $\begin{array}{l}0.008^{* *} \\
(0.000)\end{array}$ & $\begin{array}{l}0.004^{* *} \\
(0.000)\end{array}$ & $\begin{array}{l}0.003^{*} \\
(0.001)\end{array}$ \\
\hline INTP & & & $\begin{array}{l}0.042^{* *} \\
(0.001)\end{array}$ & & & & $\begin{array}{l}0.053^{* *} \\
(0.026)\end{array}$ & $\begin{array}{l}0.035^{* *} \\
(0.005)\end{array}$ \\
\hline $\mathrm{CAB}$ & & & & $\begin{array}{l}-0.005 \\
(0.003)\end{array}$ & & & $\begin{array}{l}-0.007 \\
(0.003)\end{array}$ & $\begin{array}{l}-0.007 \\
(0.003)\end{array}$ \\
\hline YVAR & & & & & $\begin{array}{l}0.222 \\
(0.581)\end{array}$ & & $\begin{array}{l}0.075 \\
(0.582)\end{array}$ & $\begin{array}{l}0.228 \\
(0.741)\end{array}$ \\
\hline EY & & & & & & $\begin{array}{l}0.116^{* * *} \\
(0.013)\end{array}$ & $\begin{array}{l}0.135^{* * *} \\
(0.009)\end{array}$ & $\begin{array}{l}0.254^{* * *} \\
(0.042)\end{array}$ \\
\hline constant & $\begin{array}{l}-0.107 \\
(0.176)\end{array}$ & $\begin{array}{l}0.225 \\
(0.348)\end{array}$ & $\begin{array}{l}-0.140 \\
(0.180)\end{array}$ & $\begin{array}{l}-0.068 \\
(0.174)\end{array}$ & $\begin{array}{l}-0.086 \\
(0.180)\end{array}$ & $\begin{array}{l}-0.107 \\
(0.182)\end{array}$ & $\begin{array}{l}-0.095 \\
(0.183)\end{array}$ & $\begin{array}{l}0.224 \\
(0.333)\end{array}$ \\
\hline No. of Observation & 108 & 108 & 108 & 108 & 108 & 108 & 108 & 108 \\
\hline $\begin{array}{l}\text { Country } \\
\text { FE }\end{array}$ & Yes & Yes & Yes & Yes & Yes & Yes & Yes & Yes \\
\hline Time FE & No & Yes & No & Yes & No & No & No & Yes \\
\hline \multicolumn{9}{|l|}{ Diagnostic test } \\
\hline M-Wald test & {$[0.155]$} & {$[0.069]$} & {$[0.471]$} & {$[0.226]$} & {$[0.342]$} & {$[0.212]$} & {$[0.103]$} & {$[0.214]$} \\
\hline
\end{tabular}

italic values denote main variable of interest

$* * *, * * *{ }^{*} 1 \%, 5 \%$ and $10 \%$ significance level; []$=p$ value 
Received: 23 March 2020 Accepted: 4 October 2020

Published: 30 October 2020

\section{References}

1. Agnello L, Sousa RM (2015) Can re-regulation of the financial sector strike back public debt? Econ Model 51:159-171

2. Ahmed HA (2020) Dynamics between the budget deficit and the government debt in the United States: a nonlinear analysis. Stud Nonlinear Dyn Econ 1 (ahead-of-print)

3. Arby MF (2001) Long-run trend, business cycle \& short-run shocks in real GDP

4. Argentiero A, Cerqueti R (2019) Public debt management and tax evasion. Macroecon Dyn. https://doi.org/10.1017/S136510051900036

5. Baig MT, Abiad MA (2005) Underlying factors driving fiscal effort in emerging market economies (No. 5/106). International Monetary Fund

6. Beqiraj E, Fedeli S, Forte F (2018) Public debt sustainability: an empirical study on OECD countries. J Macroecon 58:238-248

7. Berti K, Salto M, Lequien M (2012) An early-detection index of fiscal stress for EU countries (No. 475). Directorate General Economic and Financial Affairs (DG ECFIN), European Commission

8. Blanchard OJ, Chouraqui JC, Hagemann R, Sartor N (1991) The sustainability of fiscal policy: new answers to an old question. NBER Working Paper (R1547)

9. Bohn H (1995) The sustainability of budget deficits in a stochastic economy. J Money Credit Bank 27(1):257-271

10. Bohn H (1998) The behavior of US public debt and deficits. Q J Econ 113(3):949-963

11. Bohn $\mathrm{H}$ (2007) Are stationarity and cointegration restrictions really necessary for the intertemporal budget constraint? J Monet Econ 54(7):1837-1847

12. Bohn H (2008) The sustainability of fiscal policy in the United States. Sustain Public Debt 15-49

13. Bond SR (2002) Dynamic panel data models: a guide to micro data methods and practice. Port Econ J 1(2):141-162

14. Cavalcanti MA, Vereda L, Doctors RDB, Lima FC, Maynard L (2018) The macroeconomic effects of monetary policy shocks under fiscal rules constrained by public debt sustainability. Econ Model 71:184-201

15. Celasun O, Kang JS (2006) On the properties of various estimators for fiscal reaction functions (No. 6-182). International Monetary Fund

16. Checherita-Westphal C, Ždárek V (2017) Fiscal reaction function and fiscal fatigue: evidence for the euro area (No. 2036). ECB Working Paper

17. Daniel B, Shiamptanis C (2010) Fiscal risk in a monetary union. Manuscript, University at Albany-SUNY

18. Dombi A, Dedák I (2019) Public debt and economic growth: what do neoclassical growth models teach us? Appl Econ 51(29):3104-3121

19. de Boyrie ME, Pavlova I (2016) Dynamic interdependence of sovereign credit default swaps in BRICS and MIST countries. Appl Econ 48(7):563-575

20. Esposito M (2015) A model for public debt sustainability and sovereign credit risk in the Eurozone. Econ Notes Rev Bank Finance Monet Econ 44(3):511-530

21. Fournier JM, Fall F (2015) Government debt and fiscal frameworks, Annex 2. The Government Debt Limit. OECD Working Paper, ECO/CPE/WP1 (2015) 7/ANN2

22. Ghosh AR, Kim JI, Mendoza EG, Ostry JD, Qureshi MS (2013) Fiscal fatigue, fiscal space and debt sustainability in advanced economies. Econ J 123(566):F4-F30

23. Ghosh AR, Ostry JD, Qureshi MS (2013) Fiscal space and sovereign risk pricing in a currency union. J Int Money Finance 34:131-163

24. Hamilton JD, Flavin MA (1986) On the limitations of government borrowing: a framework for empirical testing. Am Econ Rev 76(4):808-819

25. Herwartz H, Rengel M (2018) Size-corrected inference in fiscal policy reaction functions: a three country assessment. Empir Econ 55(2):391-416

26. Islam ME, Biswas BP (2005) Public debt management and debt sustainability in Bangladesh. Bangladesh Dev Stud 31(1/2):79-102
27. IMF (2003) Debt sustainability in low income countries-towards a looking strategy. Int Monet Fund Staff Policy Dev Rev Pap 19(8):159-170

28. Jarmuzek M, Vesperoni ER (2018) The role of debt profile vulnerabilities in sovereign distress. Appl Econ Lett 25(13):928-935

29. Joy J, Panda PK (2020) An empirical analysis of sustainability of public debt among BRICS nations. J Public Aff e2170

30. Judson RA, Owen AL (1999) Estimating dynamic panel data models: a guide for macroeconomists. Econ Lett 65(1):9-15

31. Kaur B, Mukherjee A, Ekka AP (2018) Debt sustainability of states in India: an assessment. Indian Econ Rev 53(1-2):93-129

32. Maebayashi N, Konishi K (2019) Sustainability of public debt and inequality in a general equilibrium model. Macroecon Dyn. https://doi. org/10.1017/S1365100519000336

33. Magazzino C, Mutascu M (2019) A wavelet analysis of Italian fiscal sustainability. J Econ Struct 8(1):19

34. Mahmood T, Rauf SA (2012) Public debt sustainability: evidence from developing country. Pak Econ Soc Rev 23-40

35. Makin AJ (2005) Public debt sustainability and its macroeconomic implications in ASEAN-4. ASEAN Econ Bull 22(3):284-296

36. Marquez N (2000) Debt sustainability in the ECCB area. Soc Econ Stud 49(2/3):77-108. http://www.jstor.org/stable/27865196

37. Motoyama T (2019) Sustainability of public debt under physical and human capital accumulation in an overlapping generations model. J Econ 127(1):19-45

38. Pesaran MH (2007) A simple panel unit root test in the presence of crosssection dependence. J Appl Econ 22(2):265-312

39. Poghosyan $\mathrm{T}$ (2018) How do financial cycles affect public debt cycles? Empir Econ 54(2):425-460

40. Renjith PS, Shanmugam KR (2018) Sustainable debt policies of Indian state governments. Margin J Appl Econ Res 12(2):224-243

41. Stolbov M (2014) The causal linkages between sovereign CDS prices for the BRICS and major European economies. Econ Open-Access OpenAssessment E-J 8(2014-26):1-43

42. Sujithan KA, Avouyi-Dovi S (2013) The links between some European financial factors and the BRICS credit default swap spreads

43. Tanner E, Samake I (2008) Probabilistic sustainability of public debt: a vector autoregression approach for Brazil, Mexico, and Turkey. IMF Staff Pap 55(1):149-182

44. Trehan B, Walsh CE (1991) Testing intertemporal budget constraints: theory and applications to US federal budget and current account deficits. J Money Credit Bank 23(2):206-223

45. van Aarle B, Engwerda J, Weeren A (2018) Effects of debt mutualization in a monetary union with endogenous risk premia: can Eurobonds contribute to debt stabilization? Struct Change Econ Dyn 44:100-114

46. Westerlund J (2007) Testing for error correction in panel data. Oxf Bull Econ Stat 69(6):709-748

47. Wiggins V, Poi B (2001) Testing for panel-level heteroskedasticity and autocorrelation. [Online] http://www.stata.com/support/faqs/statistics/ panel-level-heteroskedasticityand-autocorrelation/. Accessed 20 March 2015

48. Wilcox DW (1989) The sustainability of government deficits: implications of the present-value borrowing constraint. J Money Credit Bank 21(3):291-306

49. World Bank (2019) International Economics Dept. Development Data Group. World development indicators. World Bank

50. Zanna LF, Buffie EF, Portillo R, Berg A, Pattillo C (2019) Borrowing for growth: big pushes and debt sustainability in low-income countries. The World Bank Econ Rev 33(3):661-689

\section{Publisher's Note}

Springer Nature remains neutral with regard to jurisdictional claims in published maps and institutional affiliations. 